\title{
Consumers Attitude and Purchase Intention towards User Generated Content- The Role of Brand Engagement, Perceived Credibility, Perceived Benefit and Perceived Risk
}

\author{
D.O.I - 10.51201/Jusst12604 \\ http://doi.org/10.51201/Jusst12604 \\ Dr. Smriti Mathur, Assistant Professor \\ Babu Banarasi Das University, Lucknow \\ Ms. Akanchha Singh, Assistant Professor \\ School of Management Sciences, Lucknow
}

\begin{abstract}
Marketing sector has undergone a paradigm shift in its practices which results in shifting of power from firms to customers. The advent of Content marketing is one such important paradigm shift for how brands do business. It allows the enterprise to go beyond adding economic value and add intellectual assets to the ecosystem of knowledge. Latest form of Content marketing is User Generated Content. The rise of user-generated content has brought a new creator into the arena: the consumer i.e. it is a strategy through which customers are turned into ambassadors. This research paper is concerned with understanding the purchase intention of customers with the use of electronic word of mouth with special reference to fashion industry. The present study is based on both primary and secondary data. Primary data is collected through questionnaire from 300 consumers of fashion products. Analysis of Data Is done with the help of SPSS. Secondary data was collected from review of books, research papers and various articles related to UGC.
\end{abstract}

Key Words: User Generated Content, Fashion, Content, Customers, etc.

\section{Introduction}

The brick and mortar selling philosophy is currently surrounded by a virtual skeleton in which content marketing is vital in changing the mindset of consumers. This traditional paradigm has been challenged by new models and technologies that transfer significant power over the critical activities i.e. crafting effective communication and developing innovative new products etc. to consumers (O'Hern, Kahle, 2013). The Big new source of innovation was the advent of Web 2.0 which has enabled a host of new services and possibilities on the Internet. With the next iteration of the internet after web 1.0, Web 2.0 which is referred to as the second generation of 
web-based services, emphasizes on UGC, usability and interoperability i.e. this allowed user to generate their own content and upload it to a website. This facilitates creativity, collaboration and communication. Marketers have also realised the importance of UGC and they use this as a powerful weapon in their arsenal. We define UGC as self-generated content by users based on their personal experience, expressed in the form of different medium (such as texts, images, video recordings, sound recording, blog posts, testimonials, podcasting, forums) using different platforms (such as social media, Buzz Feed, wiki) shared with other users or firms.

\section{$\underline{\text { Methodology }}$}

Design and Sampling: This was descriptive and applied research carried out in India. Descriptive research design focus on particular dimension or aspect of the problem. It includes what the study is all about, what techniques of gathering data will be adopted, how much material will be needed, where can the required data can be found and with what time period should the data be related, processing and analysis of data and lastly, reporting the findings. Primary data was collected through Questionnaire. Simple statistical studies such as averages, percentages etc. are used in descriptive studies. After descriptive research, analytical research was done, primarily concerned with testing hypothesis and interpreting relationships. Analytical study employs advanced statistical techniques. Structural equation modelling has been used in this paper. A snowball sampling technique was used. Snowball sampling or chain-referral sampling is defined as a non-probability sampling technique in which the samples have traits that are rare to find. This is a sampling technique, in which existing subjects provide referrals to recruit samples required for a research study. An online structured questionnaire was developed using Google forms. The link of the questionnaire was sent through e - mails, Whats App, Facebook and other social media platforms. The participants were encouraged to roll out the survey to as many teachers as possible. Thus, the link was forwarded to teachers apart from the first point of contact. After receiving the link, they clicked that link and were auto directed to the information about the study.

Data Collection: An online self-reported questionnaire was developed by the invigilators contained 13 questions including four sections. First section is concerned 
with demographic characteristics of the respondents (Gender, Age, Educational organization and specialization). Second section is concerned with User generated content related dimension questions (Brand Engagement, Perceived Credibility, Perceived Benefit and Perceived Risk). Third section is concerned with attitude of consumers towards user generated content. Forth section is concerned with the impact of attitude of consumers towards user generated content on purchase intention. This was online study.

Data Analysis Method: After the collection of the data, SPSS version 20 and AMOS version 19 was used for analysis of data. Descriptive statistics (Frequency, mean, SD) was used to describe demographic characteristics and online teaching related questions. Inferential statistics (Structural Equation Modelling) was used for finding the impact of Brand Engagement, Perceived Credibility, Perceived Benefit and Perceived Risk factors on consumers attitude towards user generated content. Also, to find the impact of consumers attitude towards user generated content on purchase intention.

Proposed Model: For the purpose of this study, thus, it is imperative to examine the relationship between Brand Engagement, Perceived Credibility, Perceived Benefit and Perceived Risk factors and consumers attitude towards user generated content. Also, this model examines the relationship between consumers attitude towards user generated content and purchase intention. 


\begin{tabular}{|l|l|}
\hline Brand Engagement & $\begin{array}{l}\text { Brand engagement is the process of forming an } \\
\text { emotional or rational attachment between a consumer } \\
\text { and a brand. }\end{array}$ \\
\hline Perceived Credibility & Credibility can be defined as believable. \\
\hline Perceived Benefit & $\begin{array}{l}\text { Perceived benefit refers to the perception of the positive } \\
\text { consequences that are caused by a specific action. }\end{array}$ \\
\hline Perceived Risk & $\begin{array}{l}\text { Risk perception is the subjective judgement that people } \\
\text { make about the characteristics and severity of a risk. }\end{array}$ \\
\hline Attitude towards products & $\begin{array}{l}\text { attitude can be defined as the set of beliefs and } \\
\text { emotions a consumer holds for a particular } \\
\text { brand/product/service which determine the perception } \\
\text { of that consumer towards the former. }\end{array}$ \\
\hline Purchase Intention & $\begin{array}{l}\text { Purchase intentions are a measure of the respondent's } \\
\text { attitude towards purchasing a product or availing a } \\
\text { service. }\end{array}$ \\
\hline
\end{tabular}

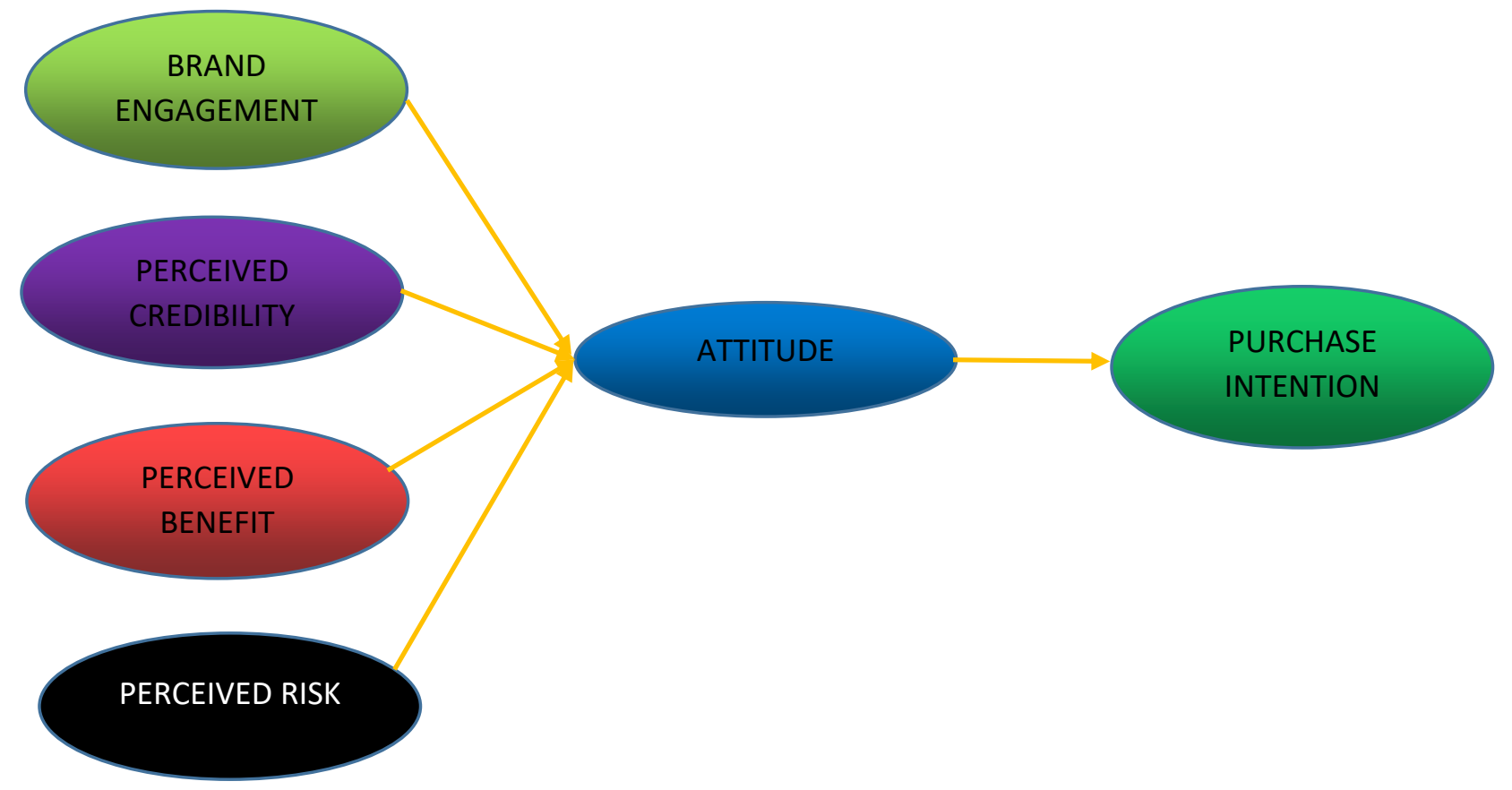

Figure 1: Conceptual framework related to Consumers attitude and Purchase

\section{Intention}


Construct Measurement and Reliability: The variables used in the proposed model are shown in Table 1. Brand Engagement, Perceived Credibility, Perceived Benefit and Perceived Risk factors, attitude of consumers towards user generated content and purchase intention were measured using Likert type scale: 1 - "Strongly Disagree", 3 - "Neutral" and 5 - "Strongly agree".

Mean score for all variable statements has been obtained by adding all the scores given by the respondents in each statement and then divided by total number of respondents. Mean score for Brand Engagement factor is highest for the item "Because I want to help other users with their problems by replying to their posts" i.e. 4.07 which indicates that customers engage with brand by replying to the queries by other customers on social media platforms. Content marketing helps customers to get best insights about the products usage. It would be prudent to get some more advice from actual consumers of the product. Mean score for perceived credibility factor is highest for the item "Trustworthy" i.e. 4.05 which indicates that customers find credence on information shared by users on various social media platforms. Mean score for perceived benefit factor is highest for the item "Timely" i.e. 4.07 which indicates that customers attitude is affected by the timely availability of information on social media platforms. Mean score for perceives risk factor is highest for the item "I think relying too much on UGC by Fashion brands page on social media platform would involve more financial risk" i.e. 4.05 which indicates that customers are aware about the financial risks involved in relying too much on information shared on social media platforms. Mean score for attitude towards purchasing factor is highest for the item "I wish to try new fashion trends" i.e. 4.01 which indicates that people are inspired by the user generated content and are motivated to try new products offered by brands

Mean score for purchase intention is highest for the item "I predict that I should use new fashion pattern suggested by users of pages" i.e. 4.00 which indicates that most of the respondents purchase intention towards adopting new fashion pattern is affected by the information shared by the actual users of that pattern. 
Table 1: Model variables and their mean

\begin{tabular}{|c|c|c|}
\hline Variables & Items & $\operatorname{Mean}(N=301)$ \\
\hline \multirow{5}{*}{$\begin{array}{l}\text { Brand } \\
\text { Engagement } \\
\text { Factors }\end{array}$} & $\begin{array}{l}\text { Because I like to compare myevaluation of } \\
\text { the fashion brand with other users' }\end{array}$ & 3.89 \\
\hline & $\begin{array}{l}\text { Because I can express my joy about a good } \\
\text { experience }\end{array}$ & 3.83 \\
\hline & $\begin{array}{l}\text { Because I feel good when I can tell others my } \\
\text { trial success }\end{array}$ & 4.01 \\
\hline & $\begin{array}{l}\text { Because I want to express my support to the } \\
\text { users who posted the messages }\end{array}$ & 3.94 \\
\hline & $\begin{array}{l}\text { Because I want to help other users with their } \\
\text { problems by replying to their posts }\end{array}$ & 4.07 \\
\hline \multirow{5}{*}{$\begin{array}{l}\text { Perceived } \\
\text { Credibility } \\
\text { Factors }\end{array}$} & Unbiased & 3.94 \\
\hline & Dependable & 3.93 \\
\hline & Trustworthy & 4.05 \\
\hline & Good & 3.87 \\
\hline & Valuable & 3.92 \\
\hline \multirow{4}{*}{$\begin{array}{l}\text { Perceived } \\
\text { Benefit Factor }\end{array}$} & Appropriate & 4.01 \\
\hline & Timely & 4.07 \\
\hline & Uptodate & 3.86 \\
\hline & $\begin{array}{l}\text { Useful for making purchase both effective } \\
\text { and efficient }\end{array}$ & 3.95 \\
\hline \multirow[t]{2}{*}{$\begin{array}{l}\text { Perceived Risk } \\
\text { Factor }\end{array}$} & $\begin{array}{l}\text { I think relying too much on UGC by Fashion } \\
\text { brands page on social media platform would } \\
\text { involve more product risk }\end{array}$ & 3.93 \\
\hline & $\begin{array}{l}\text { I think relying too much on UGC by Fashion } \\
\text { brands page on social media platform would }\end{array}$ & 4.05 \\
\hline
\end{tabular}




\begin{tabular}{|c|c|c|}
\hline & involve more financial risk & \\
\hline \multirow{5}{*}{$\begin{array}{l}\text { Attitude towards } \\
\text { purchasing }\end{array}$} & I think positively towards purchasing & 3.92 \\
\hline & I like purchasing online & 3.87 \\
\hline & I wish to try new fashion trends & 4.01 \\
\hline & My attitude towards fashion changes & 3.94 \\
\hline & $\begin{array}{l}\text { It is wise to refer to online shared content for } \\
\text { decision making }\end{array}$ & 4.07 \\
\hline \multirow{3}{*}{$\begin{array}{l}\text { Purchase } \\
\text { Intention }\end{array}$} & I will transact with fashion brand in future & 3.86 \\
\hline & $\begin{array}{l}\text { I intend to try new pattern of fashion brand in } \\
\text { future }\end{array}$ & 3.95 \\
\hline & $\begin{array}{l}\text { I predict that I should use new fashion pattern } \\
\text { suggested by users of pages. }\end{array}$ & 4.00 \\
\hline
\end{tabular}

Cronbach's alpha index is used to measure the internal consistency of questions. Internal consistency means that some questions have been taken into consideration to measure a common concept. In practice, they have also similar scores. The results are displayed in the table 2.This analysis has been performed using SPSS20 software. Cronbach's alpha value should be greater than 0.70, the obtained Cronbach's alpha value of the variables is higher than 0.70 .

\begin{tabular}{|c|c|c|}
\hline \multicolumn{3}{|c|}{ Reliability Statistics } \\
\hline Cronbach's Alpha & $\begin{array}{c}\text { Cronbach's Alpha Based on } \\
\text { Standardized Items }\end{array}$ & N of Items \\
\hline 0.845 & 0.849 & 24 \\
\hline
\end{tabular}

Hypothesis: The objective of the study is to identify the relationship that exists between consumers attitude towards user generated content and its four determinants (Brand Engagement, Perceived Credibility, Perceived Benefit and Perceived Risk factors). Also, to identify the relationship that exists between consumers attitude 
towards user generated content and purchase intention. To this end, five hypothesis have been developed based on the relationships identified in the previous section.

H1: Brand Engagement have a positive impact on Consumers attitudetowards User Generated Content.

H2: Perceived Credibility have a positive impact on Consumers attitude towards User Generated Content.

H3: Perceived Benefit have a positive impact on Consumers attitude towards User Generated Content.

H4: Perceived Risk have a positive impact on Consumers attitude towards User Generated Content.

H5: Consumers attitude have a positive impact on Purchase Intention with special reference to fashion industry.

\section{$\underline{\text { Results }}$}

Frequency distribution of demographic variables and online teaching related question is shown in Table 2. $69.4 \%$ of respondents were female and $30.6 \%$ of respondents were male. $57.5 \%$ of respondents were between age group 21 - 30 Years, followed by $37.2 \%$ of respondents below 20 Years. $40.2 \%$ of respondents were Post graduate, followed by $27.6 \%$ of respondents who were graduates. 52.8 of respondents were student, followed by $32.2 \%$ of respondents who were working as private employee. Monthly income of $39.2 \%$ of respondents was less than 10000 , followed by monthly income of between $10000-20000$. 
Table 2: Descriptive analysis of Demographic characteristics and online teaching related questions

\begin{tabular}{|c|c|c|c|}
\hline Items & & $\begin{array}{l}\text { Total } \\
\text { Population } \\
(N=301)\end{array}$ & Percentage \\
\hline \multirow[t]{2}{*}{ Gender } & Male & 92 & 30.6 \\
\hline & Female & 209 & 69.4 \\
\hline \multirow[t]{5}{*}{ Age } & Upto 20 years & 112 & 37.2 \\
\hline & $21-30$ years & 158 & 57.5 \\
\hline & $31-40$ Years & 21 & 7.0 \\
\hline & $41-60$ Years & 6 & 2.0 \\
\hline & $61-80$ Years & 4 & 1.3 \\
\hline \multirow[t]{2}{*}{ Marital Status } & Married & 62 & 20.6 \\
\hline & Unmarried & 239 & 79.4 \\
\hline \multirow[t]{6}{*}{ Education } & Less than High School & 6 & 2.0 \\
\hline & Completed High School & 13 & 4.3 \\
\hline & Intermediate & 54 & 17.9 \\
\hline & Graduate & 83 & 247.6 \\
\hline & Post Graduate & 121 & 40.2 \\
\hline & Others & 24 & 8 \\
\hline \multirow[t]{5}{*}{ Occupation } & Student & 159 & 52.8 \\
\hline & Government employee & 9 & 3.0 \\
\hline & Private employee & 97 & 32.2 \\
\hline & Business & 3 & 1.0 \\
\hline & Other & 33 & 11.0 \\
\hline \multirow[t]{6}{*}{ Monthly Income } & Less than 10000 & 118 & 39.2 \\
\hline & $10000-20000$ & 70 & 23.3 \\
\hline & $20000-40000$ & 42 & 14.0 \\
\hline & $40000-60000$ & 26 & 8.6 \\
\hline & $60000-80000$ & 21 & 7.0 \\
\hline & More than 80000 & 24 & 8.0 \\
\hline
\end{tabular}


In order to identify the relationship that exists between consumers attitude towards user generated content and its four determinants (Brand Engagement, Perceived Credibility, Perceived Benefit and Perceived Risk factors) and to identify the relationship that exists between consumers attitude towards user generated content and purchase intention, Structural Equation Modelling is used. The proposed SEM model was tested using AMOS (Analysis of Moment Structure), software developed by IBM SPSS. (Fig 1). AMOS reports various goodness of fit measures that were tested for developed models which are summarized in Table 3. In this research, all fitness indices for the measurement model had achieved the required levels i.e. the value of CFI, TLI, NFI should be closer to 0.9. Also, the value of RMSEA should be less than 0.08 and the value of $\mathrm{X}^{2} / \mathrm{df}$ should be less than 5.0. Thus, we can accept the model.

Table 3: Goodness of Fit for models

\begin{tabular}{|l|l|l|l|l|l|}
\hline Measures & $\mathrm{X}^{2} / \mathrm{df}$ & $\mathrm{CFI}$ & $\mathrm{TLI}$ & NFI & RMSEA \\
\hline Values & 2.8 & 0.767 & 0.709 & 0.687 & 0.07 \\
\hline
\end{tabular}

In this model, Brand Engagement, Perceived Credibility, Perceived Benefit and Perceived Risk factors are employed as exogenous latent variables and attitude towards purchasing and purchase intention as endogenous latent variables. Path analysis was done to test the model and used maximum livelihood method of parameter estimation and was performed on the variance - co-variance matrix. 
Fig. 2: Proposed Model

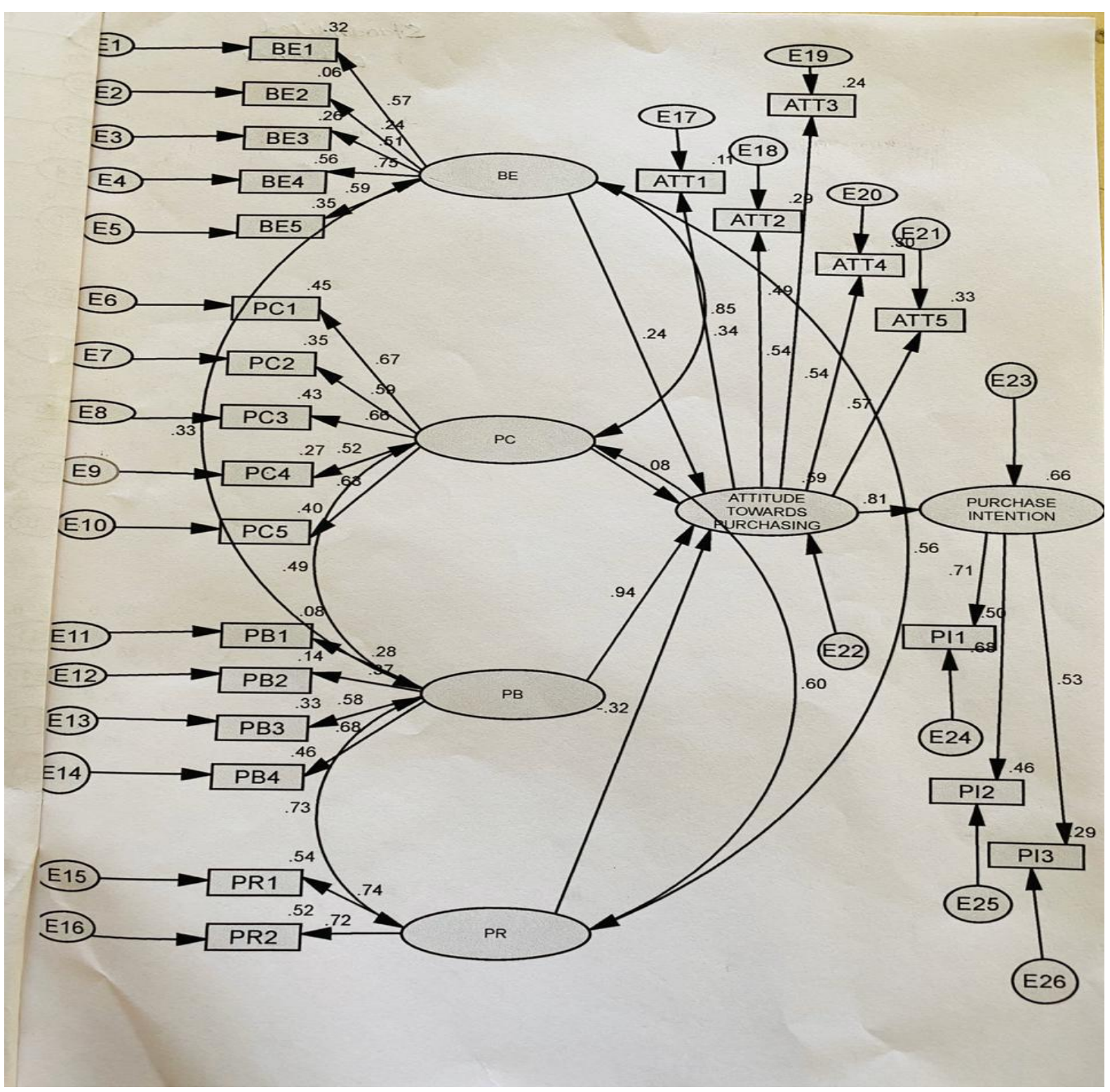

The standardized regression weights were used as they allow the researcher to compare directly the relative effect of each independent variable on the dependent variable. Table 4 presents the standardized regression estimates and allowed us to examine the direct association between the studies constructs. Since the level of significance is based on the critical ratio $(\mathrm{CR})$ of the regression estimate, when $\mathrm{CR}$ value is greater than or equal to 2.58 , it indicates a $99 \%$ of level of significance. 
Table 4. Parameters Estimated In SEM for the Proposed Model

\begin{tabular}{|c|c|c|c|c|c|c|c|}
\hline $\begin{array}{l}\text { ATTITUDE_TOWA } \\
\text { RDS_PURCHASING }\end{array}$ & $<---$ & PC & -.029 & .012 & -2.416 & $* * *$ & -.085 \\
\hline $\begin{array}{l}\text { ATTITUDE_TOWA } \\
\text { RDS_PURCHASING }\end{array}$ & $<---$ & PB & 1.040 & .400 & 2.600 & $* * *$ & .940 \\
\hline $\begin{array}{l}\text { ATTITUDE_TOWA } \\
\text { RDS_PURCHASING }\end{array}$ & <--- & PR & -.133 & .099 & -1.339 & .181 & -.321 \\
\hline $\begin{array}{l}\text { ATTITUDE_TOWA } \\
\text { RDS_PURCHASING }\end{array}$ & <--- & $\mathrm{BE}$ & .155 & .188 & .828 & .408 & .241 \\
\hline $\begin{array}{l}\text { PURCHASE_INTEN } \\
\text { TION }\end{array}$ & $<--$ & $\begin{array}{l}\text { ATTI } \\
\text { TUDE } \\
\text { TOW } \\
\text { ARDS } \\
\text { PUR } \\
\text { CHAS } \\
\text { ING }\end{array}$ & 1.722 & .366 & 4.704 & $* * *$ & .811 \\
\hline
\end{tabular}

Note: $\mathrm{N}=301$; The $\mathrm{C} \mathrm{R}$ (Critical Ratio) is the commonly recommended basis for testing statistical significance of SEM components with C.R. values beyond \pm 2.58 establishing significance at $\mathrm{p}<0.01$ level. $* * *$ indicate a highly significant at $\mathrm{p}<$ 0.01 .

\section{Discussion and Findings}

The study highlights the role of brand engagement, perceived credibility, perceived benefit and perceived risk in changing the attitude of consumers towards user generated content. Also, the role of consumers attitude on purchase intention of consumers with special reference to fashion industry. For this purpose, a questionnaire has been designed to study this and the reliability of Cronbach's Alpha test has been examined by the software SPSS 20 which is concluded to be 0.84 . This value is greater than 0.70 so the questionnaire has reliability. 
The path coefficients in the SEM are shown in Fig. 1 and the result of the hypothesis testing are summarized in table 4. The path coefficient between the attitude of consumers towards user generated content and brand engagement factor is 0.155 ( $p$ $>0.01$ ), which is positive but not significant relation indicating that Brand Engagement has no significant positive impact on Consumers attitude towards User Generated Content. This confirms that $\mathrm{H} 1$ is not supported. The path coefficient between the attitude of consumers towards user generated content and perceived credibility factor is -0.029 ( $\mathrm{p}<0.01$ ), which shows significant relation but is negative indicating that Perceived credibility has no significant positive impact on Consumers attitude towards User Generated Content. This confirms that $\mathrm{H} 2$ is not supported. The path coefficient between the attitude of consumers towards user generated content and perceived benefit factor is 1.040 ( $\mathrm{p}<0.01$ ), which is positive and significant indicating that Perceived benefit has significant positive impact on Consumers attitude towards User Generated Content. This confirms that H3 is supported. The path coefficient between the attitude of consumers towards user generated content and perceived risk factor is -0.133 ( $\mathrm{p}<0.01$ ), which shows significant relation but is negative indicating that Perceived risk has no significant positive impact on Consumers attitude towards User Generated Content. This confirms that H4 is not supported. The path coefficient between purchase intention and the attitude of consumers towards user generated content is $1.722(\mathrm{p}<0.01)$, which is positive and significant indicating that the attitude of consumers towards user generated content has significant positive impact on purchase intention. This confirms that H5 is supported.

The inferential statistics suggest that the perceived benefit has a significant impact on Consumers attitude towards User Generated Content which includes appropriateness, timely, up to date and usefulness for making purchase efficient and effective. It was also found that the attitude of consumers towards user generated content affects purchase intention also.

\section{Reference}

Rachna \& Iesha Khajuria Iesha (2017). A Study of User-Generated Content on Social Networking Sites and its Impact on Consumer-Based Brand Equity Constructs, Global Journal of Management and Business Research: E Marketing Volume 17 Issue 1 Version 1.0 Year 2017 Type: Double Blind Peer Reviewed International Research 
Journal Publisher: Global Journals Inc. (USA) Online ISSN: 2249-4588 \& Print ISSN: 0975-5853.

Widarto Rachbini (2018), The impact of Consumer Trust, Perceived Risk, Perceived Benefit on Purchase Intention and Purchase Decision. International Journal of Advanced Research. ISSN: 2320-5407, Int. J. Adv. Res. 6(1), 1036-1044.

Hale Fulya YÜKSEL(2016). Factors affecting Purchase Intention in Youtube Videos, Bilgi Ekonomisi ve Yönetimi Dergisi / 2016 Cilt: XI Say1: II

Beheruz N. Sethna*, Sunil Hazari and Blaise Bergie (2017). nfluence of user generated content in online shopping: impact of gender on purchase behaviour, trust, and intention to purchase, Int. J. Electronic Marketing and Retailing, Vol. 8, No. 4, 2017

Annika Björlin-Delmar and Gustav Jönsson Mentor: Eva Ossiansson (2015). How User-generated content can be used to reveal the brand identity and image gap , School of Business, Economics and Law at University of Gothenburg (BSc in Marketing) Gothenburg, 28th May, 2015

Matthew S. O'Herna, * and Lynn R. Kahle (2013)The Empowered Customer: User-Generated Content and the Future of Marketing, Global Economics and Management Review 18 (2013): 21-29

Azlin Zanariah Bahtar*a, Mazzini Mud (2016), The Impact of User - Generated Content (UGC) on Product Reviews towards Online Purchasing - A Conceptual Framework, FIFTH INTERNATIONAL CONFERENCE ON MARKETING AND RETAILING (5TH INCOMaR) Procedia Economics and Finance 37 ( 2016 ) $337-342$

Kaifu Zhang, Miklos Sarvary (2015). Differentiation with User-Generated Content, MANAGEMENT SCIENCE Vol. 61, No. 4, April 2015, pp. 898-914 ISSN 0025-1909 (print)_ISSN 1526-5501 (online).

Imran Anwar MIR , Kashif Ur REHMAN (2013), Factors affecting Consumers Attitude and Intentions towards User Generated Content on You tube, Management \& Marketing Challenges for the Knowledge Society (2013) Vol. 8, No. 4, pp. 637-654 